\title{
CASE COMMENT: THE VRIEND DECISION: A CASE STUDY IN CONSTITUTIONAL REMEDIES IN THE HUMAN RIGHTS CONTEXT
}

\author{
SHIRISH CHOTALIA ${ }^{*}$
}

\section{INTRODUCTION}

...discrimination against homosexuals is an historical, universal, notorious and indisputable social reality. It has been the subject of much judicial and social comment, and is already the subject of provincial legislation elsewhere in Canada.'

These words of Russell $\mathrm{J}$. and her finding in Vriend v. A.G. Alberta ${ }^{2}$ exemplify the significance of human rights laws and remedies. Russell $\mathrm{J}$. held that sections $2(1), 3$, 4, 7(1), 8(1) and 10 of the Individual's Rights Protection Act of Alberta ${ }^{3}$ (hereinafter referred to as IRPA) violated s. 15(1) of the Charter ${ }^{4}$ and were not saved by section 1. The Court read in the words "sexual orientation" into those sections. In making this finding she took judicial notice of discrimination against homosexuals. Given that courts have often taken notice of legislative facts, judicial notice of such social policy matters was not unusual, and was well within the purview of the traditional approach. ${ }^{s}$

Even advocates of restraint in judicial notice tend to focus on the standard of proof necessary to warrant the same rather than on the characterization of the facts in issue. ${ }^{6}$ Neither was the Court's finding that the omission violated s. 15 unusual in light of post-Andrews' constitutional analysis. Rather, what was unusual was the finding that the legislature did not have pressing and substantial objectives in omitting to legislate protection on these grounds. It is submitted that such a finding in and of itself authorizes the Court to remedy a constitutional encroachment without further concern for the role of the legislature.

- B.A., LL.B., LL.M. Former Commissioner to Alberta Human Rights Commission. Partner at the firm of Pundit \& Chotalia in Edmonton, Alberta.

$1 \quad$ Vriend v. A.G. Alberta (12 April 1994) Action No. 920302452 (Alta. Q.B.) [unreported] at 13 [hereinafter Vriend].

$2 \quad$ lbid.

$3 \quad$ S.A. 1980 , c. I-2.

- Canadian Charter of Rights and Freedoms, Part I of the Constitution Act, 1982, being Schedule B to the Canada Act 1982 (U.K.), 1982, c. 11 [hereinafter Charter].

s See Sopinka et al., The Law of Evidence in Canada (Toronto: Butterworths, 1992) at 976 wherein it is stated that judicial notice may be taken of facts which are: (a) so notorious as not to be the subject of dispute among reasonable persons, or (b) capable of immediate and accurate demonstration by resorting to readily accessible sources of indisputable accuracy.

6 See E.M. Morgan, "Judicial Notice" (1944) 57 Harv. L. Rev. 269, who states: "[t]o... warrant such judicial notice the probability must be so great as to make the truth of the proposition notoriously indisputable among reasonable men."

7 Andrews v. Law Society of B.C., [1989] 1 S.C.R. 143 (S.C.C.) [hereinafter Andrews]. 


\section{ANALOGOUS GROUNDS}

Section 15 encompasses "analogous grounds"8 and extends protection to "discreet and insular minorities."' Here, the Crown did not concede that sexual orientation was an analogous ground and put the Applicants to the strict proof thereof. The Court, in finding that homosexuals are entitled to protection under s. 15, was not unmindful of decisions such as Leroux v. Co-operators General Insurance Co. ${ }^{10}$ wherein unmarried persons living together were held not to constitute discreet and insular minorities, or Catholic Children's Aid Society of Metropolitan Toronto v. S.(T.) " wherein birth parents seeking post-adoption access were also denied such characterization, or Rural Route Mail Carriers of Canada, Local 1801 et al. v. Canada (A.G.) ${ }^{12}$ wherein rural mail carriers were denied analogous status. Those seeking such status must demonstrate that the distinction causes the sufferance of a disadvantage. In the case at bar, the Crown argued that the disadvantage suffered by homosexuals was attached to economic rights, being the right to work, and that economic rights are not protected under the Charter. It is submitted that the landmark cases of Andrews and Turpin exclude such reasoning by requiring scrutiny of larger social, political and legal contexts. The Court noted that the disadvantage suffered by homosexuals by being excluded from the IRPA was more fundamental than the alleged infringement of the economic right to work:

It is the denial to a group of people as a result of their personal characteristics of the same benefit and protection of rights as are provided under the Act to other similarly disadvantaged citizens of the province, including the denial of equal recognition and respect and attendant remedies. That is sufficient to constitute analogous grounds under section $15(1)$ of the Charter. ${ }^{13}$

It is further submitted that the argument fails, given that the IRPA provides protection for persons from discrimination in a number of contexts such as tenancies, provision of public services, and signs, and is not restricted to the employment context.

\section{SECTION 15 VIOLATION AND OMISSION}

After holding that homosexuals are a discreet and insular minority and thereby entitled to protection 'under $\mathrm{s}$. 15, Russell $\mathrm{J}$. held that the omission of "sexual orientation" from the Act constituted discrimination pursuant to s. 15. She observed that discrimination can emanate from a commission as well as an omission ${ }^{14}$ and that under-inclusion may violate section 15 , although, in her view, a specific denial of

\section{Ibid.}

Ibid. and R v. Turpin, [1989] 1 S.C.R. 1296 (S.C.C.) [hereinafter Turpin].

(1991), 83 D.L.R. (4th) 694 (Ont. C.A.).

(1989), 60 D.L.R. (4th) 397 (Ont. C.A.).

(1989), 29 F.T.R. 105 (T.D.) 111.

Supra note 1 at 17.

Hoogbruin v. A.G. B.C. (1985), 70 B.C.L.R. 1 (B.C.C.A.); Schachter v. Canada (1990), 66 D.L.R.

(4th) 635 (F.C.A.); Brooks v. Canada Safeway Lid., [1989] 4 W.W.R. 193 (S.C.C.). See also Schachter v. Canada (1992), 93 D.L.R. (4th) 1 (S.C.C.) [hereinafter Schachter] and TetreaultGadoury v. Canada (Employment and Immigration Commission) (1991), 81 D.L.R. (4th) 358 (S.C.C.) [hereinafter Tetreaul1-Gadoury]. 
coverage such as in Blainey v. Ontario Hockey Association ${ }^{15}$ is clearer than legislation impugned due to omission. Although McKinney v. University of Guelph ${ }^{16}$ was not referred to by the Court in Haig \& Birch v. Canada (Minister of Justice), ${ }^{17}$ Russell J. shared the Ontario Court of Appeal's view that such an omission is co-existent with the disadvantage suffered by homosexuals in the larger social, political and legal context. The Court stated that sexual orientation is directly associated with sex or gender being a legislated ground in the $A c t$, and that:

[W] ]hile there is no obligation on the Province to legislate to prohibit sexual discrimination, when it does so it must provide even-handed protection in a non-discriminatory manner, or justify the exclusion. $^{18}$

Further, in the given case the effect of the omission was held to be discriminatory: Vriend was denied legal remedy upon the termination of his employment available to other similarly disadvantaged groups.

\section{SECTION 1 ANALYSIS IN A HUMAN RIGHTS CONTEXT}

In Haig \& Birch, ${ }^{19}$ the Crown expressly disavowed reliance on s. 1 to support the validity of the impugned legislation ${ }^{20}$ in the face of a finding of a s. 15 violation. Accordingly the decision was not of assistance in Vriend. The Courts have advocated a measure of legislative deference in section 1 analysis in keeping with Andrews, Irwin $T_{0 y^{21}}$ and Edwards Books ${ }^{22}$ as opposed to a strict application of the Oakes test; ${ }^{23}$ however, the comments relate to the second branch being the proportionality branch of the Oakes test. Russell J. after examining the legislation held that, vis-à-vis the first branch of the Oakes test, there was "no evidence of a legislative objective of pressing

(1986), 54 O.R. (2d) 513 (C.A.). The Court held that the impugned legislation which specifically denied human rights protection to persons restricted to participation in athletic activities on the grounds of their sex violated $s .15$ of the Charter.

[1990] 3 S.C.R. 229 [hereinafter McKinney].

(1992), 9 O.R. (3d) 495 [hereinafter Haig \& Birch].

Supra note 1 at 22 . It may be argued to the contrary that the Charter does obligate govemments to legislate appropriate protection for "discreet and insular minorities" given the nature of human rights laws as discussed further in this article.

Supra note 17.

Canadian Human Rights Act, R.S.C. 1985, c. H-6, s. 3(1) [hereinafter CHRA].

Irwin Toy Lid. v. Quebec A.G., [1989] I S.C.R. 927 [hereinafter Irwin Toy].

$R$ v. Edwards Books and Art Lid., [1986] 2 S.C.R. 713 [hereinafter Edwards Books].

The Oakes test is as follows: the onus is on the Crown to meet two central criteria. First, the objective of the legislation must be of "sufficient importance to warrant overriding a constitutionally protected right or freedom." Secondly, there must be a balancing of the interests of society with those of individuals and groups. This proportionality aspect has three components: (a) the measures adopted must be rationally connected to the objective; (b) the means should impair "as little as possible" the right or freedom in question; (c) there must be a proportionality between the effects of the measures which are responsible for limiting the Charter right or freedom, and the objective which has been identified as of "sufficient importance". $R$. v. Oakes, [1986] I S.C.R. 103 [hereinafter Oakes]. 
and substantial concern justifying the limitation." 24 The "presumption of constitutionality"2s or judicial restraint makes such findings rare, and indeed courts should be wary of making the same without perspicuous examination of the violation in question and the apparent legislative objectives. Further, the starting point of any such analysis must be contextual. Accordingly, in dealing with the constitutionality of human rights legislation, analysis must begin with an understanding of its history, nature and status.

The Supreme Court has repeatedly espoused the "fundamental importance" of human rights laws and their "near constitutional nature." Human rights laws are not to be viewed as ordinary laws, but akin to constitutional laws, differing only in that they govern relations in the private and public sector, while the Constitution applies only to government. ${ }^{26}$ They incorporate certain basic goals of our society. Accordingly it is submitted that an analysis of a claim of Charter violation and the consequential remedies must be conducted with specific deference to the quasi-constitutional nature of human rights laws. Although deference to the legislature has been upheld in McKinney, the Court held that s. 9(a) of the Ontario Human Rights Coder had pressing and substantial objectives, as did the university policy of mandatory retirement, within the meaning of s. 1. In Irwin Toy, the Court stated that courts must question whether the government had a reasonable basis for concluding that the legislation impaired the relevant right as little as possible given the government's pressing and substantial objectives.

Further, there are tremendous similarities between human rights legislation and Charter laws. They are intertwined in their development and nature. In Andrews, McIntyre J. in dealing with the meaning of "discrimination" asks:

[W] hat does discrimination mean? The question has arisen most commonly in a consideration of the human rights Acts and the general concept of discrimination under those enactments has been fairly well settled. There is little difficulty, drawing upon the cases in this Court, in isolating an acceptable definition.... ${ }^{28}$

The objectives of both human rights and Charter rights are aimed at eradicating civil libertarian violations. Professor Hogg points out in his constitutional law text:

Supra note 1 at 27 . On the second proportionality branch of the test the Court held that denial of remedy to homosexuals is not rationally connected to the objective of protecting individual rights, and that the omission is significant, and not a minimal impaiment of section 15.

See P. Hogg, Constitutional Law of Canada, 2d ed. (Toronto: Carswell, 1985) at 324-327.

See Ontario Human Rights Commission and O'Malley v. Simpsons-Sears Lid., [1985] 2 S.C.R. 536, Robichaud v. Brennan, [1987] 2 S.C.R. 84, and Canadian National Railway Co. v. Canada (Canadian Human Rights Commission), [1987] 1 S.C.R. 1114. S. Chotalia, Canadian Human Rights Act 1994 (Toronto: Carswell Thompson Publishing, 1994) at XI(ii) (complete case citations omitted).

R.S.O. 1990 , c. H-19.

Supra note 7 at 173. 
The real threat to egalitarian civil liberties in Canada comes not from legislative and official action, but from discrimination by private persons - employers, trade unions, landlords, realtors, restaurateurs and other suppliers of goods or services. The economic liberties of freedom of property and contract, which imply a power to deal with whomever one pleases, come into direct conflict with egalitarian values....29

Recently, in Symes v. Canada, Iacobucci J. wrote:

Fortunately, in both Andrews and the present case, this court has been able to access a rich jurisprudence associated with human rights legislation. ${ }^{30}$

In Canada (A.G.) v. Martin, ${ }^{31}$ the Federal Court equated the interpretation and analysis of the BFOR ${ }^{32}$ defence to that of s. 1 of the Charter. Even in Dickason v. The Governors of the University of Alberta, ${ }^{33}$ the Supreme Court held that the s. 11.1 defence in the IRPA should be interpreted akin to the s. 1 Charter defence as outlined in Oakes but with a measure of flexibility. ${ }^{34}$ Thus even the onus of proof between the two is very similar. In human rights law:

[t]he onus of proving discrimination is upon the complainant on a balance of probabilities. Once the complainant has established a prima facie case of discrimination he or she is entitled to relief in the absence of justification by the respondent. (See Ontario (Human Rights Commission) v. Etobicoke (Borough) [1982] 1 S.C.R. 202). Even if the respondent provides justification it is open to the complainant to show that the explanation is pretextual.

Once the complainant establishes a prima facie case, the onus then moves to the respondent to establish a bona fide occupational requirement (BFOR) in the case of direct discrimination. To constitute a BFOR a limitation must be imposed honestly, in good faith, and in the sincerely held belief that such a limitation is imposed in the interests of the adequate performance of work involved with all reasonable dispatch, safety and economy, and not for ulterior or extraneous reasons aimed at defeating the objectives of human rights laws. ${ }^{35}$

This is not dissimilar from a Charter violation wherein the applicant must establish a prima facie case of a Charter violation, and then the onus shifts to the respondent to justify the breach pursuant to $\mathrm{s}$. 1 .

29 Supra note 25 at 786.

30 (1993), 161 N.R. 243 at 310.

$31 \quad$ (January 31, 1994) Doc. T-2248-92 (Fed. T.D.).

32 Acronym for bona fide occupational requirement, being the defence statutorily legislated in the Canadian Human Rights Act, an equivalent defence of either BFOR or bona fide occupational qualification (BFOQ) is found in other provincial human rights legislation.

$33 \quad$ [1992] 2 S.C.R. 1103 (S.C.C.).

34 See S. Chotalia, "The Supreme Court and Mandatory Retirement: Sanctioning the Status Quo" 4:3 Const. Forum 67.

3s See Ontario (Human Rights Commission) v. Etobicoke (Borough), [1982] I S.C.R. 202. Also see Chotalia, supra note 26 at XI(iii). 
With this understanding of the interrelationship of Charter law and human rights laws, Russell J.'s finding gains considerable credence. She held that the omission controverts the very statement of principle of the IRPA embodied in the preamble:

...recognition of the inherent dignity and the equal and inalienable rights of all persons is the foundation of freedom, justice and peace in the world...

and observed:

A legislative limitation which controverts the very principle it purports to embody is not a legitimate exercise of the legislative power for the attainment of a desirable social objective which would warrant overriding constitutionally protected rights. ${ }^{36}$

Such a violation in human rights laws of the principles of its "sister" Charter legislation cannot be upheld as a legitimate legislative exercise.

\section{REMEDY}

\section{The Supreme Court in Schachter stated:}

The first step in choosing a remedial course under s. 52 is defining the extent of the inconsistency which must be struck down. Usually, the manner in which the law violates the Charter and the manner in which it fails to be justified under $\mathrm{s}$. 1 will be critical to this determination. ${ }^{37}$

Lamer C.J. reinforced this view in his discussion of the purpose test, stating that:

[i]n some circumstances, s. 52(1) mandates defining the inconsistent portion which must be struck down very broadly. This will almost always be the case where the legislation or legislative provision does not meet the first part of the Oakes test, in that the purpose is not sufficiently pressing or substantial to warrant overriding a Charter right. ${ }^{38}$

Vriend proves the exception; although Russell $\mathrm{J}$. found that the limitation did not meet the purpose test, the striking down of the sections in their entirety was not a palatable remedy to applicants seeking to broaden benefits. ${ }^{39}$ As Lamer C.J. noted in Schachter:

Supra note 1 at 27-28.

Supra note 14 at 16.

Ibid. See also at 27: "The extent of the inconsistency should be defined: (A) broadly where the legislation in question fails the first branch of the Oakes test in that its purpose is held not to be sufficiently pressing or substantial to justify infringing a Charter right or, indeed, if the purpose is itself held to be unconstitutional - perhaps the legislation in its entirety."

The Court in Schachter refers to Nova Scotia (A.G.) v. Phillips (1986), 34 D.L.R. (4th) 633 (N.S.C.A.) wherein the court struck down a benefit given to single mothers rather than extending it to include single fathers also. However, at 28 Lamer C.J. wrote "I should emphasize before 1 move on that the above propositions are intended as guidelines to assist courts in determining what action under s. 52 is most appropriate in a given case, not as hard and fast rules to be applied regardless of factual context." La Forest $\mathrm{J}$., in a simultaneous judgment at 35, cautioned against a mechanistic approach to reading down or reading in with the checklist set forth in Oakes. See N. Duclos, "A Remedy For the Nineties: Schachter v. $R$ and Haig \& Birch v. Canada" 4:1 Cons. 
The right which was determined to be violated here is a positive right: the right to equal benefit of the law. Positive rights by their very nature tend to carry with them special considerations in the remedial context. It will be the rare occasion when a benefit-conferring scheme is found to have an unconstitutional purpose. Cases involving positive rights are more likely to fall into remedial classifications of reading down/reading in or striking down and suspending the operation of the declaration of invalidity than to mandate an immediate striking down. ${ }^{40}$

In Schachter, it was Parliament that had to equalize the provision of monetary benefits for parents under the Unemployment Insurance Act, $1971 .^{41}$ While it was clear that the concession of a s. 15 violation should at the very least result in a suspension of the declaration of invalidity, the reading in of the excluded group was not so clear. The Court grappled with the larger objective of the impugned Unemployment Insurance $A c t^{42}$ and with the objective of the provision in issue. It was not readily apparent to Lamer C.J. on the text of the provision alone that the purpose of it was to extend benefits to parents of newborns caring for them at home, a purpose which reading in the excluded group would further. On the contrary, it could have been argued that natural parents were deliberately excluded, and that the provision was specifically aimed at responding to circumstances peculiar to adoptive parents. Lamer C.J. advocates:

Without a mandate based on a clear legislative objective, it would be imprudent for me to take the course of reading the excluded group into the legislation. ${ }^{43}$

Budgetary implications further underlined his conclusion given that the excluded group sought to be included vastly outnumbered the group to whom benefits were already extended. The Court cautioned that an extension in such a case would constitute a substantial intrusion into the legislative domain, given that Parliament was better equipped to assess the larger budgetary situation: it was significant that Parliament did amend the impugned provision to equalize payment to natural and adoptive parents but reduced the total amount payable to each.

Lamer C.J.'s direction in Schachter was to continue the broad contextual approach in determination of remedy with consideration to the following factors in analyzing whether to use severance or reading in:

Forum 22 at 24 [hereinafter "A Remedy for the Nineties"] for academic criticism of Schachter. See also R. Rempel, "The Possibilities of Schachter: A Response to Professor Duclos - A Response to Professor Duclos" 4:4 Const. Forum 106 for academic comment on the possibilities of "reading in" as outlined in Schachter.

42 In Tetreault-Gadoury, supra note 14 at 370 , La Forest J. held (citing Bliss v. A.-G. Can. (1978), 92 D.L.R. (3d) 417 at 418 ) that the objective of the legislative scheme was to "create a social insurance plan to compensate unemployed workers for loss of income from their employment and to provide them with economic and social security for a time, thus assisting them in returning to the labour market." 
(i) the extent to which the method by which to extend a statutory provision can be ascertained with sufficient degree of precision on the basis of constitutional analysis as opposed to making "ad hoc choices from a variety of options, none of which was pointed to with sufficient precision by the interaction between the statute in question and the requirements of the Constitution. ${ }^{\text {nd4 }}$

(ii) the consistency of extension with legislative objectives;

(iii) the size of the group to be included by extension and budgetary considerations;

(iv) consideration of the significance of remaining portions of a statute and asking whether the assumption that the legislature would have enacted the remaining portion is a safe one. "If the remaining portion is very significant, or of a long-standing nature, it strengthens the assumption that it would have been enacted without the impermissible portion. ${ }^{\text {45 }}$

In Haig \& Birch, the Court noted that the omitted words "sexual orientation" could easily be determined with precision, ${ }^{46}$ as did Russell J. in Vriend. ${ }^{47}$ Professor Duclos raises some valid points in her criticism of Krever J.A.'s analysis on this point. She argues that the reasoning used to hold that an extension remedy was insufficiently precise in Schachter could lead to a similar finding in Haig \& Birch.$^{48}$ Indeed, akin to the Schachter reasoning per Lamer C.J., the purpose of the legislation in both Haig $\&$ Birch and in Vriend could be viewed as excluding protection on the basis of "sexual orientation".$^{49}$ Professor Roach is also critical when he writes:

How is a court to determine whether extension of under-inclusive legislation respects the role of the legislature? Any remedy, whether extending or striking down legislation will depart from the actual intent of the legislature. In the absence of an express severability clause, courts should focus on respect for the role of the legislature and not rely on fictional attributions of legislative intent. ${ }^{\mathbf{5 0}}$

Accordingly it is submitted that the analysis of precision, legislative objective and safety for purposes of remedy must also be cognizant of the context and nature of the impugned legislation, in this case human rights legislation (as discussed above). One should question why legislative objectives should be a factor for consideration in the absence of pressing and substantial government objectives. While generally the constitutional remedy in under-inclusive legislation should be predicated upon the "twin guiding principles" of respect for the role of the legislature, and also the giving of

Ibid. at 19.

Ibid. at 24.

Supra note 17 at 506.

Supra note 1 at 33. Section 3(1) of the Act states: "For all the purposes of this Act, race, national or ethnic origin, colour, religion, age, sex, marital status, family status, disability and conviction for which a pardon has been granted are prohibited grounds of discrimination." Section 2 of the same Act deals with the purpose of the Act.

"A Remedy for the Nineties", supra note 39 at 25.

The various human rights statutes of the provinces and federal government are not uniform in enumerated grounds.

K. Roach, Constitutional Remedies in Canada (Aurora, Ont: Canada Law Book, 1994) at 14-53. 
effect to the purposes of the Charter, ${ }^{51}$ one must ponder why this should be the case in the absence of pressing and substantial government objectives. Given that most significant decisions of the Supreme Court have evolved out of legislation wherein the government had such pressing and substantive objectives, ${ }^{52}$ there is little guidance in such cases. At the very least, legislative intent should not be confused with legislative objectives.

In Haig \& Birch, in addressing legislative objectives, Krever J.A. stated:

A mere reading of s. 2 of the Canadian Human Rights Act ... discloses that to read into s. 3(1) the words "sexual orientation" would be less intrusive than the total destruction of the objective that would result from striking the provision down. ${ }^{53}$

Russell J. agreed with the reasoning of Krever J.A. The Crown tried to focus its arguments upon "legislative intent". Requiring courts to surmise about legislative intent creates an inappropriate gloss upon the "legislative objectives" test as well as the "safety" test. Although in Haig \& Birch there was evidence of "the commitment of successive Ministers of Justice on behalf of their governments to amend the legislation to add sexual orientation to the list of prohibited grounds, ${ }^{154}$ Schachter does not require courts to delve into cabinet correspondence and the history of rejected bills dealing with the omitted amendments. Russell J. correctly noted:

In my view, Lamer C.J.C. did not contemplate the need for such evidence of government support in Schachter when he spoke of the need to consider the legislative intent. Though the court must concern itself with the way in which legislatures act generally, it ought not to transgress into the political arena by conducting an assessment of the political views of the Government or the Opposition. 55

Regarding budgetary impacts of reading in "sexual orientation" into the Act, the Court in Vriend correctly held that such impact was not substantial enough to warrant the result in Schachter.

Lastly, the significance of striking down the entire benefit-conferring section, and/or statute is not in keeping with the special and fundamental nature of human rights legislation. Krever J.A. in Haig \& Birch wrote of it in this way:

If it were unsafe to assume that Parliament would have enacted the protection to categories of persons enunciated in s. 3(1) of the Canadian Human Rights Act if sexual orientation were to be included, the section would have to be struck down ... it is surely safe to assume that Parliament would favour

s1 Schachter, supra note 14.

52 For example, in Edwards Books, supra note 22, Dickson C.J. held that while the provincial legislation abridged freedom of religion, the desirability of giving families a common pause day in the retail industry was pressing and substantial; in Irwin Toy Lid., supra note 21, legislation violating freedom of expression was held to meet pressing and substantial objectives of protecting vulnerable society members even though its application was not confined to them.

s3 Supra note 17 at 506.

s4 Ibid. at 507.

ss Supra note 1 at 34-35. 
extending the benefit of s. 3(1) of the Act to homosexual persons over nullifying the entire legislative scheme ... enlightened human rights legislative policy has evolved in this country. It is now an integral part of our social fabric. It is therefore inconceivable to me that Parliament would have preferred no human rights Act over one that included sexual orientation.... ${ }^{36}$

\section{CONCLUSION}

We should not forget that "The letter of the law killeth. The spirit of the law saveth." 57 Given that the courts have a duty to scrutinize legislation to ensure its constitutionality, their remedial powers must not be unduly restricted, particularly in a human rights context. Given the filial relationship between human rights laws and Charter laws, a violation of Charter rights by human rights laws cannot be upheld as a legitimate legislative exercise. The Vriend case, wherein a lack of pressing government objectives were found, demonstrates the need to clearly affirm the supremacy of human rights laws to inappropriate legislative control. This is not to abdicate from the traditional respect for the legislative function, but rather to safeguard the sanctity of human rights legislation. It is true that human rights laws tread upon complex policy issues. In the Vriend case, as in other "sexual orientation" cases, "underlying the debate is the fact that the traditional nuclear family is only one form of family as we experience it in Canada today." ${ }^{58}$ However, the courts must remain the final guardians of discrimination and civil liberties violations. Human rights laws entrench the goals of an enlightened society.

Supra note 17 at 507-8.

2 Cor. 3:5-6.

D. McAllister, "Sexual Orientation and Spousal Status: The Unresolved Question" 3 N.J.C.L. 288 at 300. See also D. McAllister, "Recent Sexual Orientation Cases" 2 N.J.C.L. 354 and "Sexual Orientation and Section 15" 1 N.J.C.L. 377 on the same point. See also M. Eaton, "Patently Confused: Complex Inequality and Canada v. Mossop" 1 Rev. of Const. Stud. 203. 